\title{
The collapse of the state industry in Romania: between political and economic drivers
}

\author{
Cătălin Deacu* \\ University of Bucharest, Romania
}

Deindustrialisation is one of the most complex and dynamic processes that have shaped the global economy over the past half century. This article aims to highlight the factors behind this process and their implications in the national state industry. In Romania, deindustrialization has profoundly marked recent history, after 1990, through the closure of hundreds of factories and the loss of over 2.5 million jobs. The process resulted in the rising of unemployment and of the crime rate and generated the phenomenon of poverty. The research results were obtained by studying the economic policies adopted by eight governments between 1990 and 2006. The study underlines that deindustrialization in Romania was a consequence of an accumulation of internal and external factors whose impact was amplified by the failure of government policies.

Key Words: deindustrialization, Romania, industrial policy, unemployment.

Article Info: Received: July 25, 2016; Revised: October 28, 2018; Accepted: November 10, 2016; Online: November 30, 2016.

\section{Introduction}

Romania has a tradition of over a century and a half in the industrial field. The existence of significant natural resources in the soil and subsoil triggered the development of industries that propelled the Romanian State among the top world producers of oil, gas and salt (Ionescu \& Gogoneață, 2007:269). After 1878, when the Romanian state obtained its independence, the industry development was influenced directly by the domestic and international political state. Between 1878 and 1918, during the Old Kingdom, the oil industry and some light industries such as textiles and food industries have developed.

\footnotetext{
* Correspondence adress

Address: University of Bucharest, Faculty of Geography, 1 Nicolae Balcescu Avenue, 010041, Bucharest, Romania.

Phone: +0213153074 | Email: catalin_deacu@yahoo.com
} 
During 1918-1944, the period of Greater Romania, the mining, oil, gas and salt as well as the arms industry have developed. Between 1948 and 1989, during the socialist period, the political leadership has encouraged the development of sectors such as heavy industry, especially the automobile and machinery industry and the expansion of the extractive industry. After 1990, the post-December period, the deindustrialization process covered all industries.

\section{The Rise and Decline of Romanian Industry}

After obtaining independence in 1878, adopted fiscal policies, which had targeted exemption from taxes on rail-way transport of goods and the establishment of customs protectionism, spurred national manufacturing activity. Between 1893 and 1906, 215 new factories were established, the total number of enterprises reaching 254 (Bud, 2015:235). In 1913, as a result of foreign investments, Romania was ranked fourth in the world, after the US, Russia and Mexico, in the production of liquid fuel (Buzatu, 2009:31).

In the interwar period, the industrial sector contributed over a third of the gross domestic product (GDP), the country's most developed sectors being that of the oil and gas industry. In 1936, Romania ranked third in the world oil trade (Buzatu, 2009:297). However, the country was lacking in the manufacturing of mining, petroleum, energy and agricultural equipment (Constantinescu, 2014:40). For this reason, industrial production and labour productivity were six times and respectively, three times lower than the European average (Murgescu, 2010:264). Between 1918 and 1944, the industry had an uneven zoning development, with over $50 \%$ of units being concentrated in three regions, Bucharest-Prahova Valley, central Transylvania and Banat, while the historical provinces of Moldova, Oltenia and Dobrogea were processing only 12 \% of the total national industrial production (Rădoi, 1969:58).

After the establishment of the socialist regime, in the period 1948-1989 Romania recorded a process of forced industrialization that aimed to develop heavy industry and the means of production to the detriment of the production of consumer goods. By Law no. 119/1948, more than 1,600 enterprises were nationalized, a process that led to the formation of the socialist state industry (Radoi, 1969:65). The process of industrialization, based on annual and fiveyear plans, was a copy of the Soviet model of development and constituted, to authorities, the only way of achieving state progress (Jowitt, 1971:112). It imposed the transfer of population from villages to cities to ensure the necessary workforce for the new industrial possibilities and contributed thereby to the country's urbanization (Enyedi, 1990:27). The period 1948-1953 was characterized by the emergence of the socialist proletariat, with the contribution of more than 800,000 people in rural areas (Peritore, 1999:194). The industry became the economical branch that had benefited from the largest public investment. In the 1960-1966 five-year plan, the authorities have financed the development of heavy industry with 78\% of the total state investment (Nicolescu, 2011:245). Following the investment effort, in 1977 the country's industrial output was 38 times greater than the one recorded in 1938 (Șandru, 1978:88). During 19501989 , the share of the automobile industry had doubled, and the chemical 
industry tripled (Murgescu, 2010:346). Although industrialization was the main vector of modernization of the country, disparities between regions had been reduced only partially, Moldova and Oltenia remaining still the most underdeveloped provinces, accounting for $11.3 \%$ and $7.2 \%$ of the total industrial production (Pop, 1986:83).

The first signs of decline of the Romanian industry were specific to the 19801989 period. Between these years, the average growth rate of industrial production was 3.3\%, more than three times lower than that of the 1971-1979 period (Adumitrăcesei, 2001:57). Following the forced industrialization, branches with oversized capacity resulted, and also large consumers of natural resources and energy, which proved uncompetitive in the wake of the international oil crisis (Niculescu \& Adumitrăcesei, 2001:15). During 1970-1981, the political turmoil in the Middle East led to higher prices of oil, by 30 times, which led to raw material supply bottlenecks and operation of businesses at reduced capacity, remaining at $80 \%$ (Stan, 2009:44). This process resulted in the production of products at higher costs and led to the loss of external competitiveness of the national economy (Dumitrescu, 1993:51). Unlike other socialist states, the Romanian authorities did not initiate a process of economic reconversion in order to boost the development of sectors with lower consumption of natural resources, but instead encouraged intensive energy-consuming activities and the construction of industrial giants (Stroe, 2000:69). Moreover, the decision of the Ceausescu regime to prepay the external debt of the country led to overuse of production means and the reduction of otherwise required investments for technological modernization. During 1978-1986, the value of state investments in machinery, equipment and technologies had decreased three times, from 1.3 billion dollars to only 429 million dollars (Stroe, 2000:69).

Consequently, in 1989, in some sectors such as the petrochemical industry, glassmaking and Pharmaceuticals, the degree of wear of fixed assets exceeded 50\% (Dumitrescu, 1993:48). Restrictions imposed on the population to save the interests of state industry as well as the rationalization of electricity and heat, led to the worsening of living conditions and low labour productivity. In 1989, when the Ceausescu regime was overthrown, Romania recorded the lowest rate of labour productivity in the whole socialist camp (Adumitrăcesei, 2001:57). In these circumstances, the deindustrialization of Romania proved an inevitable phenomenon in the post-revolutionary period. Deindustrialization led to the dismantling of 4.145.500 jobs across the economy and produced a total export deficit worth 157 billion dollars (Fota, 2011:60). During the 1990-2000 period, which remained in the collective mind as the transition, the value of the industry in GDP decreased from $46.2 \%$ in 1989 to $27.6 \%$ in 2000 (NSI, 2001). Also quoted during this period, the share of labour in the sector was reduced from $38.1 \%$ to $26.9 \%$, this process having adverse consequences on a social level such as the occurrence of the unemployment and poverty phenomenon. During the period 1990-2000, in Romania the unemployment rate increased from 0 to $11.5 \%$ and by 2000 , the poverty rate had reached a level of $28.9 \%$ (World Bank, 2007:1). The lack of government measures to restructure and streamline the industry resulted in the 1992-1998 period, in a tripling of the number of labour disputes and a 64\% increase in the rate of crime (Marin \& Mereuță, 2001:119). In the context of the loss of jobs in the big cities, in Romania, a process of neo- 


\section{Cătălin Deacu}

ruralization appeared, atypical for Europe, which involved people returning to villages and resuming agricultural activities (Adumitrăcesei, 2001:88). During the pre-EU accession period, between 2000 and 2006, the GDP industrial output continued to decline from $27.6 \%$ in 2001 to $24.2 \%$ in 2006 (NIS, 2008). The process had a nationwide impact. In 2002-2008, the labour force engaged in industry decreased in 34 out of the 41 counties. Most affected were the monoindustrial cities, especially those specializing in mining and metallurgy.

The study on identifying the factors that caused the deindustrialization of Romania is relevant given that, until now, there has been no thorough scientific research on the causes of this pathological process that led to the ruin of the state property and the disappearance of more than 2.5 million jobs in the sector. 26 years after the 1989 December revolution, the Romanian authorities do not have a report on this phenomenon.

The research conducted shows that the deindustrialization of Romania was a consequence of an accumulation of internal and external factors that have had a major impact due to the mistakes of the industrial policy of eight successive governments between 1990 and 2008. The study identifies external conjuncture and administrative measures directly affecting the activity of state industry.

Identifying internal and external factors that have led to deindustrialisation in conjunction with the presentation of adverse consequences, can be a start for the authorities to adopt the necessary measures to solve current social problems in the territory, especially in areas rich in natural resources where poverty rises thus facing an accentuated depopulation phenomenon.

In support of the above considerations, we give as arguments some data and indicators that could provide insight into the decline of the Romanian industry: The GDP industrial output during 1990-2006, dynamics of industry labour during 1990-2008, the dynamics of unemployment in 1990-2006, GDP based economical sector composition during 1990-2006.

So far, in Romania, the authorities have yet to establish a correlation between the administrative measures adopted and the decline of national industry. Officials do not have an assessment of damage caused by deindustrialization.

The study includes an analysis of the deindustrialisation process in Romania, at a national level, during 1990-2006. In this research were used as reference the years 1990 (the first after the fall of the communist regime), 2000 (marking the end of the transition, i.e. the period of transformation of the state economy in an economy dominated by private capital), and 2006 (the end of accession to the European Union).

\section{Deindustrialization: ideological, (geo)political and economic drivers}

During 1990-2006, deindustrialization was a result of wrong economic policies, blotched privatization and of the decision to close down state enterprises adopted by governments or imposed by external creditors. During a spam of 16 years eight governments have implemented reforms that have directly influenced the industrial sector's activity. During the Petre Roman government (1990-1991), the state industry came to a standstill due to the financial collapse of exports. Between 1991 and 1992, during the government of Theodor Stolojan, firms were 
undercapitalized by government measures to confiscate the currency and by limiting domestic lending, due to reforms imposed by the IMF. Nicolae Văcăroiu's Government (1992-1996) delayed privatization and restructuring measures were not initiated for electoral reasons. Between 1997 and 1999, during the government terms of Victor Ciorbea and Radu Vasile government programs have been initiated to close unprofitable enterprises instead of making them cost effective, at the request of IMF. In 1999-2000, the Mugur Isărescu Government initiated a new industrial policy to encourage only industries with a competitive potential at the European level. The Adrian Năstase government (2000-2004) realized privatization with strategic investors that have proven to later on go bankrupt. The Călin Popescu Tăriceanu Government (2004-2008) stopped subsidizing and has not taken steps to streamline unprofitable branches such as mining.

Collapse of exports and industry input into financial jam

(Petre Roman's government 1990-1991)

One of the external factors that have caused the decline of the state industry was reducing exports by half, following the dissolution of the Council for Mutual Economic Assistance (COMECON or CAME). COMECON was dissolved on June 30th, 1991, but during the socialist regime it was the main market for Romanian products. In 1990 and 1991 the value of exports of domestic industry products decreased by $44.9 \%$ and $73.8 \%$ compared to the level recorded in 1989 . This process generated a deficit of exports worth $\$ 7.6$ billion dollars and led to loss of 1.695.000 jobs. The collapse in exports led to a first internal factor of deindustrialization, financial blockage for businesses. Now lacking their main source of funding, state enterprises began to record outstanding payments between each other, called arrears. In 1991, the worth of arrears was about 1.650 billion lei. In the absence of outlets to continue their activity, industrial units were forced to produce on stock. This process resulted in the development of unsaleable goods which boosted the sector's financial blockage.

Decapitalising state enterprises through fiscal measures and reforms imposed by IMF (Theodor Stolojan's government 1991-1992)

Another factor that negatively influenced manufacturing activity was the government's decision to nationalize businesses currency. On November 6th, 1991, the government established an exchange rate of 180 lei / dollar, compared to 60 lei/ dollar, and imposed on state businesses to sell the currency found in their accounts to the National Bank. Nationalization of the currency led to decapitalizing the sector and thus businesses were unable to carry out imports of the much needed technology in order to modernize their equipment, even though the wear rate of fixed assets exceeded $50 \%$ in most industries. An external factor which affected the functioning of the sector was the demand of the International Monetary Fund (IMF) to limit domestic lending by increasing interest rates. Following the grant agreement signed by the Government with the IMF, on April 11th, 1991, interests on loans increased by $80 \%$, sparking industrial units being unable to access loans needed to continue their work through the Romanian banks. The decision to limit 
lending growth was a consequence of inflation, another factor that affected domestic production activity. In 1992, Romania registered an inflation rate of $210.4 \%, 39.4 \%$ higher than in 1991 . To get rid of cheap money, most companies resorted to unplanned expenses and made unprofitable investments that have negatively influenced the production and investment budgets. It is estimated that in 1992, due to inflation, $50 \%$ of the population lived in poverty.

Delaying privatization and the lack of industrial restructuring measures for electoral reasons (Nicolae Văcăroiu's Government 1992-1996)

A new internal factor that influenced directly the industry sector was the government's decision to delay the privatization process. This process encouraged corruption within the state and hindered private sector development. Although in this period a legislative framework was initiated to accelerate the sale of assets and to initiate the process of mass privatization, in 19962,871 enterprises were sold, a low number compared to that intended by officials.

Another factor that produced deindustrialization was forced listing of over 6,000 companies on RASDAQ. In the absence of transparency and exchange conduct rules, RASDAQ encouraged abusive privatizations that led to dismantling assets and selling them for scrap. Consequently, in 2015, when this market was disbanded only 915 companies functioned out of the 6000 initially listed. A factor that influenced domestic manufacturing activity was delaying the restructuring of unprofitable enterprises and the maintenance of subsidy policies, especially for electoral reasons. The main method to streamline the sector was, however, dismissal of employees. In 1996, the Romanian industry had 2.74 million people working, 700,000 less than in 1992.

IMF-imposed government programs to disband unprofitable enterprises instead of restructuring them (Victor Ciorbea government's 1997-1998)

An external factor that influenced deindustrialization in Romania was the IM's and World Bank 's decision to grant the Government a loan conditioned by the closure of unprofitable units instead of making them cost effective. Constrained by foreign creditors to adopt radical measures, the government started in 1998 the FESAL program - meant for industrial restructuring, and the ASAL program - for agroindustrial restructuring.

This administrative measure, the closure of unprofitable companies without trying to increase their profitability, was an internal deindustrialization factor, which remained in the public mind as shock therapy. Based on the FESAL and ASAL programs dozens of enterprises and agro-industrial complex were privatized or liquidated. At the end of 1997, 17 industrial units included in the FESA program, were in disbanding - liquidation procedure. Another factor that targeted directly the industrial branches was the restructuring of the mining sector, on 6 September 1997. Based on this program over 17,000 miners were fired in 1997, and the closure of unprofitable exploits, instead of adopting measures to streamline them, kicked off. 
IMF-imposed government programs to disband and divide enterprises

(Radu Vasile's government 1998-1999)

An external factor that influenced the activity of the industrial sector was the Government's decision to seal a loan agreement with IMF on August 5th, 1999. Under the agreement, the government had assumed the closure of 40 unprofitable businesses and the reduction of losses in the state industry by $22 \%$. A feature of the agreement was the existence of lists drafted by the foreign creditors with state enterprises that were to be closed. Consequently, the Government decided to liquidate 32 industrial units and to privatize another 49 companies. An internal factor that had a significant impact on the future development of the sector, was the decision to divide the state monopoly in the energy sector - RENEL, and rail transport - SNCFR in autonomous companies. This process failed to lead to a more efficient and profitable business, but instead encouraged the expansion of corruption.

Changing industrial policy in the context of Romania's accession to EU

(Mugur Isărescu's government 1999-2000)

A factor that influenced the domestic industrial sector's activity was the ongoing policy of state monopolies dividing into autonomous companies. In 1999-2000, the Romgaz National Company, specializing in natural gas extraction and CONEL, in the electricity sector, had been restructured by partial division methods. These processes and measures involved the dismissal of employees, which resulted in further reducing the number of employees in the industry sector. An external factor that would influence decisively the future development of the sector was to launch negotiations for Romania's accession to the European Union on February 15th, 2000. On March 16th, 2000 the Government adopted the National Strategy for Romania's economic development which aimed to revive and develop industries with competitive potential in line with European market requirements. Simultaneously, the government gave up supporting highly subsidized industries such as mining.

Foreign investor privatizations going bankrupt

(Adrian Năstase's Government 2000-2004)

During 2000-2004, one of the key internal factors which concerned the proper functioning of the industrial sector was poor management of state enterprises. In 2000 , within the Romanian industrial sector, the intensive energy consuming activities had a share of $28 \%$, one of the highest in Europe. The energy losses attributed to industrial units, including Sidex, Petrom, Petromidia, RAFO Onesti, totalled over 30 billion lei. As a result of the existence of state companies suffocated by debt and losses on March 20th, 2002, the Government Law of accelerating the privatization process was passed, allowing the sale of these assets at the symbolic price of 1 euro. On December 15th, 2003, the privatization process was completed in the territory, following the sale of over 3,000 companies. In total, in 2000-2004, the Romanian state had obtained over 3 billion euros from privatizations. Due to 
poor management, there were lax conditions of sale and the proceeds from some of the industrial enterprises were lower than their real market value. This process resulted in missed privatizations that have not led to a more efficient business, but to actually stopping them, a good example being the Rafo Onesti refinery.

The collapse of inefficient industries by stopping subsidies

(Călin Popescu Tăriceanu's Government 2004-2008)

During 2004-2008, one of the key internal factors that produced deindustrialization was the acceleration in closing down mines and quarries that were considered to be unprofitable, thus leading to the collapse of mining plants. Out of a total of 29 mining companies, 12 are currently in liquidation or insolvent due to the liquidation of the units responsible for their supply of natural resources. Another factor that negatively influenced the industry were missed privatizations. For example, the largest copper processing refineries in the cities Zlatna and Baia Mare fell in the possession of investors who brought them to the brink of bankruptcy. Failure to initiate processes of economic reconversion in mining areas led to increased population dependency to the forms of social assistance, to the appearance of poverty and subsequent depopulation of these areas otherwise rich in natural resources.

\section{Consequences of deindustrialization in Romania}

In Romania, deindustrialization had multiple negative consequences both economically and socially. Economically, the process of deindustrialization has meant continuing decline in the economic contribution of the traditional industry to the composition of GDP, following the disappearance of hundreds of businesses. INS data reveals that, during 1990-2006, the GDP industrial output almost halved from $40.5 \%$, as it was in 1990, to $23.9 \%$ in 2006 (Figure 1).

It has to be noted that since 1998, the industry had a below $30 \%$ GDP output. This percentage is lower than the $30.8 \%$ output of 1938 , before initiating forced industrialization. A direct consequence of deindustrialisation has been the declining output of industrial labour force of the total employment capacity of the country. During 1990-2006, industrial sector workforce was reduced substantially, especially in the transition period, ending in 1999 at a minimum percentage of 24.4\% (Figure 2). During the accession period between 2000 and 2006 there was an increase in this indicator as a result of direct foreign investments made in Romania, which led to the creation of new jobs.

During the transition period, the decrease of the GDP industry output and of the labour force from this sector triggered an atypical process at European level, the neo-ruralisation, which involved the migration of population from cities to villages. This process favoured by the population's restitution of agricultural land confiscated during the socialist period, was manifested in the context that the services sector was weak and had no capacity to absorb the dismissed labour force the industry generated. 


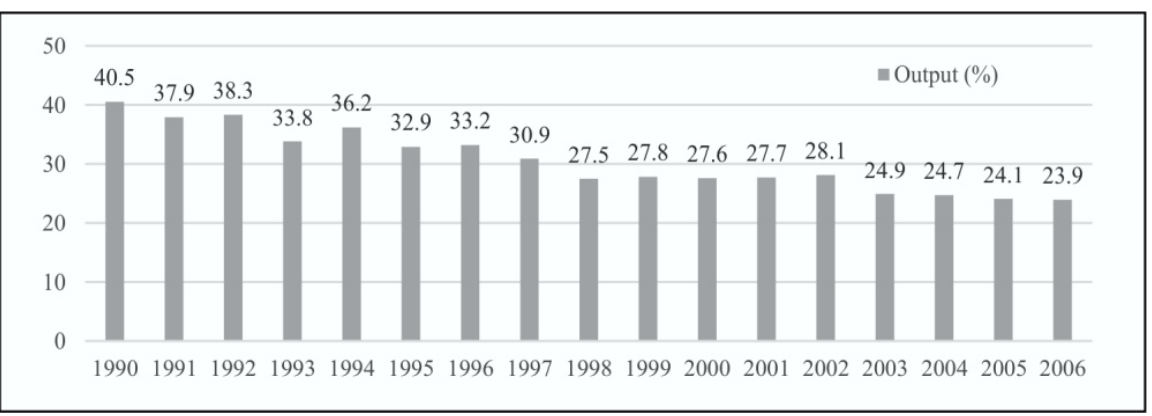

Figure 1. GDP Industrial output between 1990 and 2006

Source: NSI, 2008

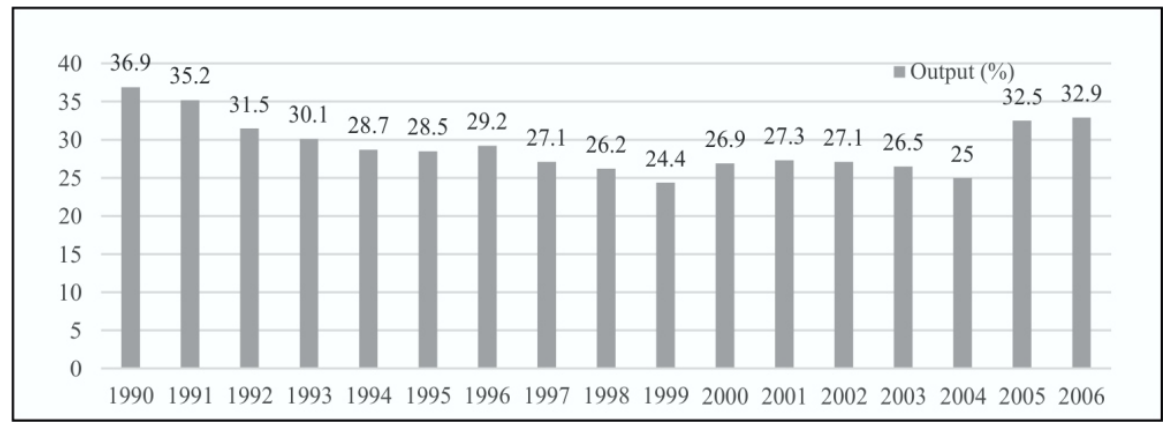

Figure 2. Labour force dynamics in the industrial sector between 1990 and 2006

Source: NSI, 2008

While, during the transition period, the share of industry employment decreased from $36.9 \%$ in 1990 to $26.2 \%$ in 1998, the share of agriculture employment increased from 28, $2 \%$ in 1990 to $36.8 \%$ in 1998. In 2000, the agricultural sector has recorded an additional workforce of over 3,000,000 people (Figure 3).

Consequently, deindustrialization led to changes in the economic profile of the country. During the transition period, Romania was transformed from a highly industrialized state, as it was in 1990, in an industrial-agrarian state. In the period 1990-2000, while the GDP industrial output was reduced by $12.8 \%$, the agricultural output in GDP decreased by $7.8 \%$, which shows that the sector could not ensure prosperity for the infusion of population in urban areas (Figure 4).

From the social point of view, deindustrialization led to exponential growth in unemployment ratios. This process had a significant impact especially during the transition period when the unemployment rate rose from $0 \%$, as it was in 1990 , to a record high of $11.5 \%$ in 1999 (Figure 5 ).

Rising unemployment attracted the phenomenon of poverty, the areas most affected being the mono-industrial towns where there were no economic reconversion programs to provide an alternative way to make a decent living for the dismissed workers. In Romania, between 1995 and 2000, the poverty rate rose from $25.4 \%$ to $28.9 \%$. In 1999, according to the World Bank, $22 \%$ of the population lived below the poverty line. 


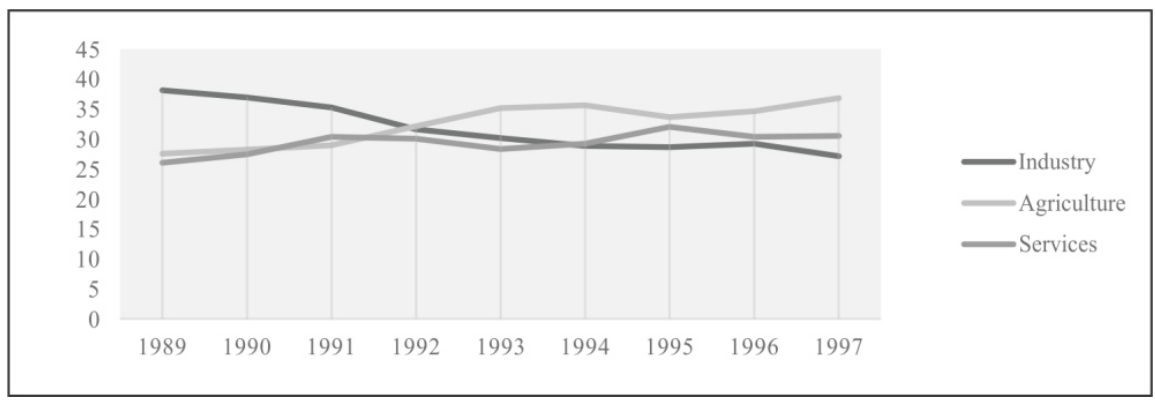

Figure 3. Dynamics of the economic sectors composing the GDP between 1989 and 1998 Source: NSI, 2001

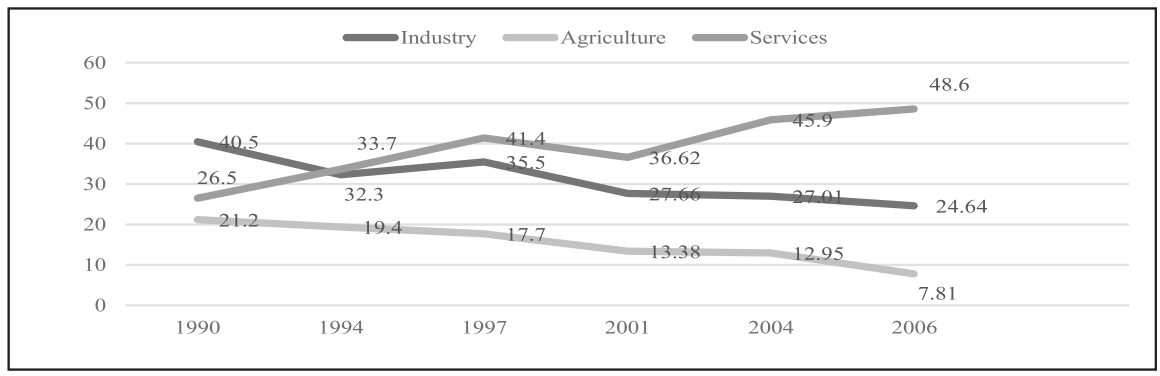

Figure 4. GDP Economic sectors between 1990 and 2006

Source: NSI, 2008

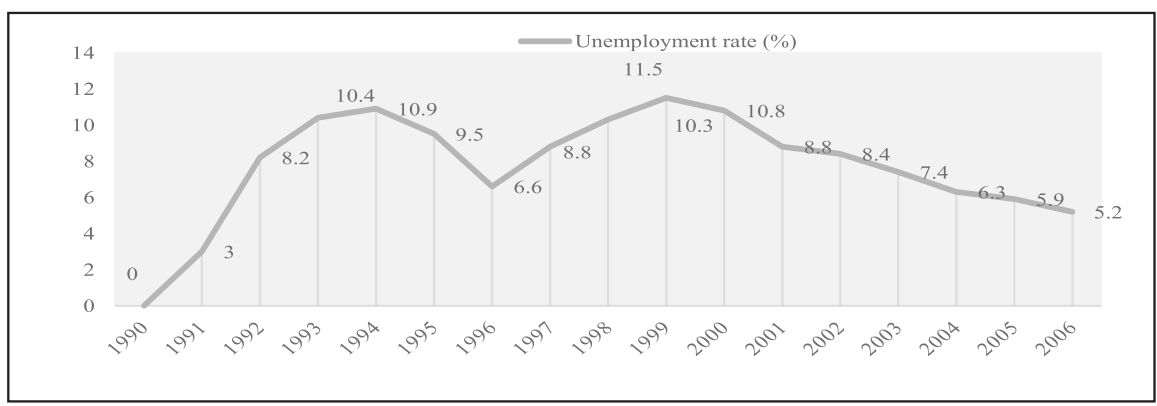

Figure 5. Unemployment dynamics between 1990 and 2006

Source: NSI, 2008

The growth of poverty has led to an increasing crime rate. The number of sentenced persons per 100,000 inhabitants rose from 303 in 1992 to 496 in 1997. Job losses also generated an increased state of tensions within the society. Between 1992 and 1999, the number of labour disputes, meaning strikes and other forms of protest, tripled, from 195 to 653. In 1999, over one million persons were involved in labour disputes. The accession period had recorded, however, a reduction in unemployment to almost half, from $10.3 \%$ in 2000 to $5.3 \%$ in 2006 , due to the development of the services sector and private equity. 


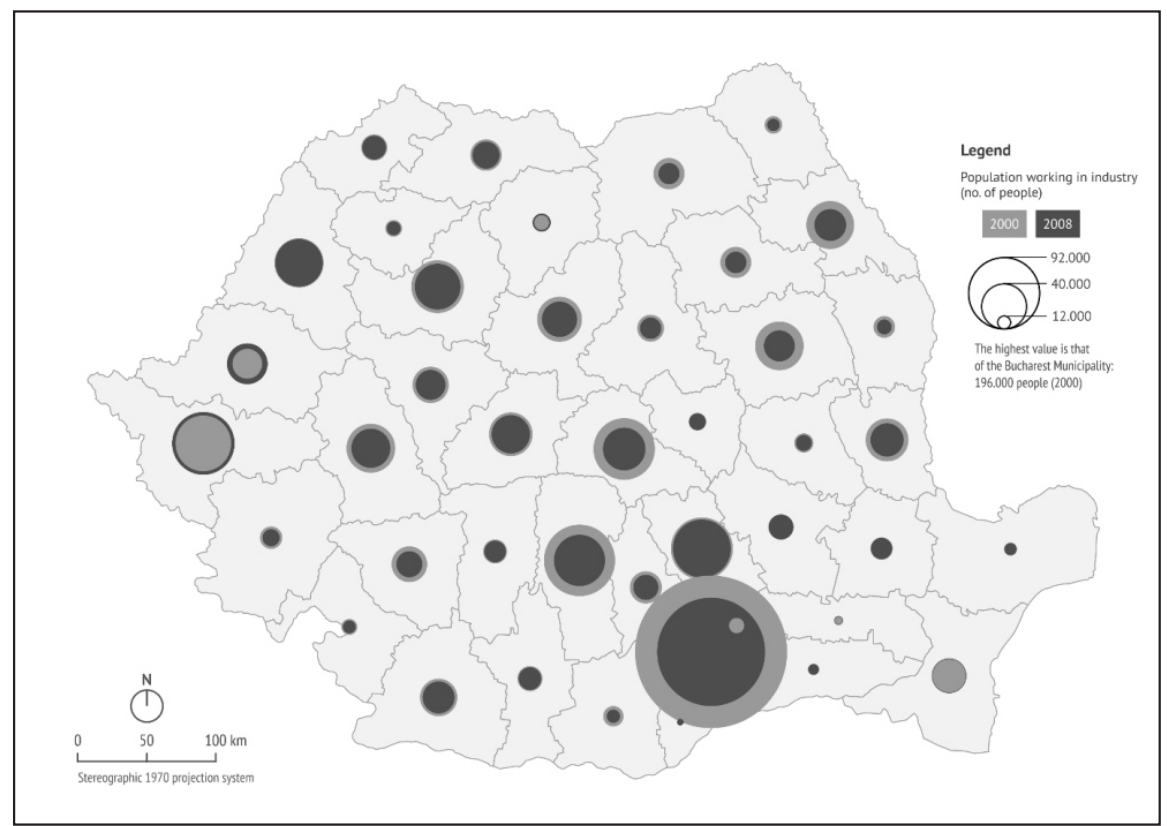

Figure 6. The territorial distribution of labour in the industry in 2000 and 2008 Source: NSI, 2009

In Romania, deindustrialization was a pathological process that generated negative socio-economic changes nationwide. During the accession period, the labour force engaged in industry decreased in 34 counties from a total of 41 (Figure 6). Statistical analysis of the data can conclude that, in 2000-2008, one third of the counties (14) had a strong or accentuated decline of labour in the industry sector and 20 counties declined moderately or poorly. The reasons for this were the businesses closing and the restructuring process which involved the dismissal of employees. The only counties where there was an increase in the number of employees were Bucharest $(+56 \%)$, Ilfov (47.2\%), Arad (+ 26.9\%), Bistrița-Năsăud (18.7\%), Timiș (+ 11\%), and Constanța (4\%). In Ialomița County, the share of labour force was kept constant.

The regions most affected by the deindustrialization process, in which there was a decreased number of industry employees in all of the component counties, were the North East, Centre and South West regions. The regions less affected by this process were those whose contribution to GDP was higher, like the Bucharest-Ilfov and West Region. Consequently, workforce reduction, both in developed regions and counties as much as in the poorest ones, contributed to the maintenance and widening of the development gaps in the territory.

\section{Conclusions}

In Romania, the process of deindustrialization in the post-December period is rooted in the mistakes of industrial policy in the decade 1980-1990, the years of crisis of the Romanian socialist regime. Industry inherited from the socialist regime 
had a degree of wear of fixed assets of over $40 \%$ in the majority of industries. The lack of investment and low productivity triggered a process of deindustrialization after 1990, proven to be an inevitable phenomenon. Deindustrialization was the result of several factors, internal and external, that have had a major impact because of industrial policies, which led to bankruptcy, initiated by eight successive governments that ruled the country.

The external factors identified were the dismantling of the COMECON market (1990-1991), loan agreements with foreign creditors, IMF and the World Bank (1991-1999), and changing the strategy of industrial policy in the context of Romania's accession to the EU (2000-2006). The internal factors identified are the financial blockage of businesses (1990-1991), the loss of export markets (19901992), the lack of access to bank loans for refurbishments and the decapitalisation of businesses by seizing their currency (1992), the acceleration in inflation (from 1990 to 1994), delays in the privatization process (1992-1996), restructuring methods involving the dismissal of employees (1992-2000), initiating liquidation process for the industry under the FESAL and ASAL government programs (1997-1999), poor management of state-owned enterprises (1990-2006), and failed privatizations (1998-2006).

In Romania, deindustrialization was manifested mainly in the years 1990-2000, during the transition period. The process resulted in the closure of hundreds of businesses and the dismissal of more than 2.5 million employees. In the absence of any economic reconversion strategies, deindustrialization led to the rising of unemployment, of the poverty rate and of the crime rate. Unlike other European countries, due to the insufficient development in the services sector, in Romania a phenomenon of neo-ruralisation appeared which involved the migration of population from cities to villages and its involvement in agricultural activities. Due to underdevelopment of agriculture, the neo-ruralisation did not bring prosperity, but instead it has increased poverty by increasing de dependency of the population on social aid.

During the accession period, the government's decisions to stop subsidizing certain industries has had a negative impact especially on mono-industrial towns specializing in mining and metallurgy. Although deindustrialization manifested nationally in 34 of the 41 counties, the Romanian authorities do not have, at this time, an assessment of the damage caused by this pathological process, which could provide a starting point for a better understanding and a solution for socioeconomic problems in the territory.

\section{References}

Adumitrăcesei I.D., (2001), Fapte și idei economice. Despre români și pentru români, București, Editura Economică .

Bud N., (2015), La hotarul dintre milenii. Mineritul încotro?, București, Editura Academiei Române.

Buzatu G., (2009), O istorie a petrolului românesc, Iași, Casa Editorială Demiurg.

Constantinescu N., (2014), Istoria Economică a României, Vol. II, București, Editura Economică.

Dumitrescu F., (1993), Căile stabilității monetare, București, Editura Academiei Române.

Enyedi G., (1990), New Basis for Regional and Urban Policies in East-Central Europe, Pecs, 
Centre for Regional Studies, Discussion Papers, no. 9.

Fota D., (2011), Reforma reformei românești care a produs dezindustrializarea economiei naționale și a provocat un deficit extern de 157 miliarde dolari, București, Editura Universitară.

Ionescu C., Gogoneață E., (2007), Cunoaște România-membră a Uniunii Europene, București, Editura Economică.

Jowitt K., (1971), Revolutionary Breakthroughs and National Development. The case of Romania, 1944-1965, California, University of California Press.

Marin D., Mereuță C., (2001), Economia României 1990-2000, București, Editura Economică.

Murgescu B., (2010), România și Europa, Acumularea decalajelor economice (1500-2010), Iași, Editura Polirom.

Nicolescu N.C, (2011), Enciclopedia Șefilor de Stat și de Guvern ai României, București, Editura Meronia.

NSI (Institutul Național de Statisică) (2001), Anuarul Statistic al României, București.

NSI (Institutul Național de Statisică) (2008), Anuarul Statistic al României, București.

Peritore P., (1999), Thirld World Environmentalism. Case Studies form Global South, Florida, University Press of Florida.

Pop G., (1986), România Geografie Economică Partea I, Ediția a doua, Cluj Napoca, Universitatea Cluj Napoca.

Rădoi A. H., (1969), Geografia Economică a Republicii Socialiste România, București, Editura Didactică și Pedagogică.

Stan V., (2009), Falimentarea Economiei Naționale. Procesul celor opt guvernări postrevoluționare 1990-2004, București, Editura Saeculum Vizual, vol. 2.

Stroe G., (2000), Istoria Economică a României, vol. 2 - Evoluția economiei românești în anii 1970-1980: Criza datoriei externe., București, Editura Economică,

Şandru I., (1978), România Geografie Economică, București, Editura Didactică și Pedagogică.

World Bank, (2007), Romania. Powerty and Social Policy, vol. 1, p. 1.

http://adatbank.transindex.ro/html/cim_pdf392.pdf 